\title{
DAMPAK KINERJA KEUANGAN TERHADAP RETURN SAHAM PERUSAHAAN KOSMETIK YANG TERDAFTAR DI BURSA EFEK INDONESIA
}

\author{
Wahyudi \\ Universitas Islam Negeri Alauddin \\ Email:wahyudi.wahyudi@uin-alauddin.ac.id \\ Suriyanti \\ Universitas Muslim Indonesia \\ Email:suriyanti.mangkona@umi.ac.id
}

\section{Abstract}

This study aims to determine the Impact of CR, DER, and ROA on Stock Return. The research uses a theory/concept base, supported by previous studies which have similarities in variables. The object of this research is the Cosmetic Company which is listed on the Indonesia Stock Exchange. The type of data used is secondary data. Using descriptive statistical techniques and panel data regression assisted by Eviews 10.0 for data analysis. The results found that CR has a negative and significant effect on Stock Return, DER has a positive and not significant effect on Stock Return. ROA has a positive and not significant effect on Stock Return.

Keywords: CR, DER, ROA and Stock Return

\begin{abstract}
Abstrak
Penelitian ini bertujuan untuk mengetahui Dampak CR, DER dan ROA Terhadap Return Saham. Penelitian menggunakan basis teori/konsep, didukung oleh penelitian-penelitian sebelumnya yang mempunyai kesamaan variabel. Objek Penelitian ini Perusahaan Kosmetik yang terdaftar di Bursa Efek Indonesia. Jenis data yang digunakan adalah data Sekunder. Menggunakan teknik statistik deskriptif dan regresi data panel berbantuan Eviews 10.0 untuk analisis data. Hasil penelitian menemukan bahwa CR berpengaruh negatif dan signifikan terhadap Return Saham, DER berpengaruh positif dan tidak signifikan terhadap Return Saham. ROA berpengaruh positif dan tidak signifikan terhadap Return Saham.
\end{abstract}

Kata Kunci: CR, DER, ROA, dan Return Saham 


\section{PENDAHULUAN}

Saat ini perusahaan tidak lagi beroperasi hanya untuk menghasilkan laba sebesar-besarnya, namun perusahaan memiliki tujuan lain, yaitu meningkatkan kekayaan pemegang saham.informasi mengenai kinerja perusahaan sangat diperlukan untuk menarik investor menanamkan modalnya karena dapat dijadikan tolak ukur dalam berinventasi.

Perusahaan manufaktur di Indonesia berusaha untuk memproduksi barang yang berkualitas tinggi dengan penekanan biaya yang rendah dalam rangka meningkatkan daya saing baik dipasar domestik maupun dipasar global. Persaingan bisnis yang sangat ketat membuat perusahaan harus mempunyai keunggulan yang kompetitif agar dapat bersaing dan bertahan. Hal ini membuat perusahaan harus dapat mengembangakan, mempertahankan dan meningkatkan kinerja sebagai upaya menjaga kelangsungan usahanya agar dapat bersaing dengan perusahaan lain.

Kosmetik menjadi suatu kebutuhan pokok bagi sebagian orang terutama kaum wanita. Kecantikan semakin berkembang dan berkembang dari masa ke masa, bukan lagi hanya menjadi sebuah keinginan, melainkan sudah menjadi sebuah kebutuhan yang akhirnya berdampak pada semakin meningkatnya industri kosmetik di dunia, Industri kosmetik kini telah berkembang pesat. Semakin banyak perusahaan dengan berbagai macan produk dan merek menjadi salah satu bukti perkembangan industri kosmetik saat ini. Dalam menjalankan operasionalnya, perusahaan umumnya memerlukan dana tambahan untuk pengembangan usaha dan penambahan modal kerja. Untuk mendapatkan dana tersebut banyak cara yang dapat dilakukan oleh perusahaan, yang salah satunya adalah dengan menjual saham. Saham adalah surat berharga yang dikeluarkan oleh perusahaan yang berbentuk perseroan terbatas yang diperdagangkan di pasar modal.

Kinerja keuangan pada perusahaan kosmetik dapat dinilai dengan menggunakan pendekatan analisis rasio keuangan. Jika kinerja perusahaan meningkat maka nilai perusahaan akan semakin tinggi. Di bursa efek hal ini akan direspon oleh pasar dalam bentuk kenaikan harga saham. kinerja perusahaan dapat diukur dengan menganalisa dan mengevaluasi laporan keuangan. Informasi posisi keuangan dan kinerja di masa lalu seringkali digunakan sebagai dasar untuk memprediksi posisi keuangan dan kinerja dimasa depan dan hal lain yang langsung menarik perhatian pemakai seperti pembayaran dividen, upah, pergerakan harga sekuritas dan kemampuan perusahaan untuk memenuhi komitmennya ketika jatuh tempo.

Return (kembalian) adalah tingkat keuntungan yang dinikmati oleh pemodal atas suatu investasi yang dilakukan (Ang,1997). Husnan (1996) juga menyatakan bahwa return saham merupakan hasil yang diperoleh dari suatu investasi. Investasi harus benarbenar menyadari bahwa di samping akan memperoleh keuntungan tidak menutup kemungkinan mereka akan mengalami kerugian. Keuntungan atau kerugian tersebut sangat dipengaruhi oleh kemampuan investor menganalisi keadaan harga saham merupakan penilaian sesaat yang dipengaruhi oleh banyak faktor termasuk diantaranya kondisi (performance) dari perusahaan. Kendala-kendala ekteral, kekuatan 
penawaran dan permintaan saham di pasar, serta kemampuan investor dalam menganalisis investasi saham

Profitabilitas

perusahaan

merupakan fungsi dari faktor internal dan eksternal. Faktor internal merupakan faktor mikro atau faktor spesifik perusahaan yang menentukan profitabilitas. Sedangkan faktor eksternal merupakan variabel-variabel yang tidak memiliki hubungan langsung dengan manajemen perusahaan, tetapi faktor tersebut secara tidak langsung memberikan efek bagi perekonomian dan hukum yang akan berdampak pada kinerja lembaga keuangan.

Likuiditas suatu perusahaan menunjukkan bahwa suatu perusahaan mampu membayar kewajiban jangka pendeknya dengan alat-alat likuid yang dimiliki oleh perusahaan tersebut. Likuiditas perusahaan dalam penelitian ini diproksikan oleh Current Ratio. Telah dijelaskan sebelumnya bahwa kepentingan likuiditas dan rentabilitas bertentangan satu sama lain. Maka, ketika nilai LDR kecil, kemungkinan perusahaan tersebut akan mendapatkan rentabilitas yang tinggi. Dalam hal ini diharapkan pimpinan perusahaan dapat menjaga likuiditasnya. Ia harus mengetahui berapa jumlah alat likuid yang dikuasai setiap hari agar dapat memenuhi kewajiban yang segera harus dibayar. Selain harus likuid, perusahaan harus rendebel (menguntungkan atau berusaha mencari untung). Keuntungan diperoleh apabila penghasilan lebih besar daripada biaya yang dikeluarkan.

Salah satu rasio keuangan yang penting dalam analisis kinerja keuangan adalah rasio solvabilitas (leverage). Dalam praktiknya untuk menutupi kekurangan dana, perusahaan memiliki beberapa pilihan sumber dana. Pemilihan sumber dana tersebut tergantung dari tujuan, syarat-syarat, keuntungan dan kemampuan dari perusahaan. Sumber-sumber dana pada umumnya dapat diperoleh dari modal sendiri dan pinjaman (bank atau lembaga keuangan lainnya). Leverage dapat dijadikan ukuran untuk melihat baik buruknya kinerja solvabilitas suatu perusahaan. Melalui rasio ini dapat diketahui perbandingan penggunaan dana perusahaan yang berasal dari pihak luar atau pinjaman. Rasio solvabilitas menggambarkan kemampuan perusahaan dalam membayar kewajiban jangka panjangnya atau kewajibankewajibannya apabila perusahaan dilikuidasi.

Tingkat leverage yang tinggi akan mengurangi minat para invertor untuk membeli saham dan hal ini akan menyebabkan harga saham semakin menurun. Jika harga saham semakin menurun maka para investor beranggapan bahwa Penurunan harga saham akan membuat nilai perusahaan dipandang oleh para investor juga rendah. 
Invoice: Jurnal Ilmu Akuntansi

p-ISSN: 2714-6359 e-ISSN: 2714-6340

Vol. 2 Nomor 2 Agustus 2020

Tabel 1. Daftar harga saham perusahaan Kosmetik yang terdaftar di Bursa Efek Indonesia

\begin{tabular}{|c|c|c|c|c|c|}
\hline \multirow{2}{*}{ Kode } & \multicolumn{5}{|c|}{ Tahun } \\
\cline { 2 - 6 } & $\mathbf{2 0 1 4}$ & $\mathbf{2 0 1 5}$ & $\mathbf{2 0 1 6}$ & $\mathbf{2 0 1 7}$ & $\mathbf{2 0 1 8}$ \\
\hline ADES & 1.375 & 1.000 & 885 & 885 & 920 \\
\hline MBTO & 135 & 126 & 140 & 100 & 240 \\
\hline MRAT & 350 & 280 & 210 & 206 & 179 \\
\hline TCID & 17.525 & 16.500 & 12.500 & 17.900 & 15.000 \\
\hline ULVR & 32.300 & 32.700 & 38.000 & 55.900 & 45.400 \\
\hline Rata-rata & 10.337 & 10.121 & 10.347 & 14.998 & 12.348 \\
\hline
\end{tabular}

Sumber: www.idx.co.id

Berdasarkan tabel 1 diatas ratarata harga saham bergerak fluktuatif naik dan turun setiap tahunnya. Perusahan kosmetik yang terdiri dari PT. Akasha Wira International Tbk, PT. Martina Berto Tbk, PT. Mustika Ratu Tbk, PT. Mandom Indonesia Tbk dan PT Unilever Indonesia Tbk. pada tabel 1 diatas harga saham tertinggi pada PT Unilever Indonesia Tbk (ULVR) pada tahun 2017 sebesar Rp. 55.900 sedangkan harga saham terendah yakni PT. Martina Berto Tbk (MBTO) pada tahun 2017 sebesar Rp.100.

Dalam Penelitian Ignatius Oki Dewi Brata, et al (2017) berjudul Analisis Faktor-Faktor Yang Berpengaruh Terhadap Return Saham menemukan hasil ROA dan DER berpengaruh positif signifikan terhadap return saham

Berdasarkan uraian diatas, maka penulis tertarik untuk melakukan penulisan skripsi dengan judul Pengaruh Kinerja Keuangan Terhadap Return Saham Perusahaan Kosmetik yang Terdaftar di Bursa Efek Indonesia.

\section{TINJAUAN PUSTAKA}

\subsection{Kinerja Keuangan dan Laporan Keuangan}

Fahmi (2012), tujuan laporan keuangan adalah untuk memberikan informasi kepada pihak yang membutuhkan tentang kondisi suatu perusahaan dari sudut angka dalam suatu moneter. Kasmir (2016) menyatakan pihak - pihak yang memiliki kepentingan terhadap laporan keuangan adalah sebagai berikut :

a. Pemilik Saham

b. Pemerintah

c. Manajemen

d. Karyawan

e. Masyarakat Luas

\subsection{Return Saham}

Tujuan keuangan perusahaan adalah untuk memaksimumkan nilai dalam perusahaan. Tujuan ini bisa menyebabkan konflik antara pemilik perusahaan dengan kreditur, jika perusahaan menikmati laba yang besar , nilai pasar saham (dana pemilik) akan meningkat, sementara nilai hutang perusahaan (dana kreditur) tidak berpengaruh (phardono dan christiawan 2004).

Sebaliknya apabila perusahaan mengalami kerugian bahkan kebangkrutan maka hak kreditur didahulukan sementara nilai saham akan nilai menurun drastis. Jadi dengan demikian nilai saham meurpakan alat ukur yang tepat untuk mengukur keefektivitasan perusahaan, sehingga sering kali dikatakan memaksimumkan 
nilai perusahaan juga berarti memaksimumkan kekayaan perusahaan.

Menurut (Jogiyanto 2017) ada dua jenis return yaitu:

"Return realisasi (realized return) merupakan return yang telah terjadi. Return ini dihitung dengan menggunakan data historis. Return realisasi penting karena digunakan sebagai salah satu pengukur kinerja perusahaan. Return realisasi juga berguna dalam penentuan return ekspektasi (expected return) dan risiko yang akan datang."

"Return ekspektasi (expected return) adalah return yang diharapkan akan diperoleh oleh para investor di masa yang akan datang." Dari teori definisi di atas dapat diambil kesimpulan bahwa jenis return terdiri dari:

\section{a. Realisasi}

b. Ekpektasi

Jogiyanto, 2017

Return Saham $=\frac{P t-(P t-1)}{P t-1}$

R:Return Saham

$P t$ : Harga Saham Waktu Tertentu

Pt-1 : Harga Saham Periode Sebelumnya

\section{c. Faktor-faktor yang mempengaruhi return saham}

Rika Verawati (2014), terdapat beberapa faktor yang mempengaruhi return saham, antara lain:

1) Faktor Internal

2) Faktor Eksternal

\subsection{Profitabilitas}

Profitabiltas

merupakan

kemampuan perusahaan untuk menghasilkan laba atau keuntungan dari seluruh modal yang dimilikinya. Besar kecilnya kemampuan perusahaan untuk menghasilkan laba ini dapat diukur dari perbandingan antara laba dengan seluruh modal yang dimilikinya. Rasio rentabilitas sangat penting untuk mengetahui sampai sejauh mana kemampuan perusahaan di dalam menghasilkan keuntungan baik yang berasal dari kegiatan operasional maupun kegiatan non operasional. Sartono (2010:122) definisi profitabilitas adalah kemampuan perusahaan memperoleh laba dalam hubungannya dengan penjualan, total aktiva, maupun modal sendiri. Dengan demikian bagi investor jangka panjang akan sangat berkepentingan dengan analisis profitabilitas ini. ROA adalah rasio yang digunakan mengukur kemampuan bank menghasilkan keuntungan secara relatif dibandingkan dengan total asetnya.

Rasio ini mengukur kemampuan perusahaan menghasilkan laba bersih berdasarkan tingkat aset yang tertentu. ROA merupakan perkalian antara Net Profit Margin dengan perputaran aktiva. Net Profit Margin menunjukkan kemampuan memperoleh laba dari setiap penjualan yang diciptakan oleh perusahaan. Sedangkan perputaran aktiva menunjukkan seberapa jauh perusahaan mampu menciptakan penjualan dari aktiva yang dimilikinya. Apabila kedua faktor itu meningkat maka ROA juga akan meningkat. Apabila ROA meningkat maka profitabilitas perusahaan meningkat sehingga dampak akhirnya adalah peningkatan profitabilitas yang dinikmati oleh pemegang saham.

$$
\mathrm{ROA}=\frac{\text { LABA BERSIH }}{\text { TOTAL ASSET }} X 100 \%
$$

\subsection{Likuiditas}

Tingkat kemampuan suatu perusahaan untuk dapat membayar hutang-hutang jangka pendeknya sering disebut likuiditas. Perusahaan yang mempunyai cukup kemampuan untuk membayar hutang jangka pendek disebut 
perusahaan yang likuid. Sedang apabila perusahaan berada dalam keadaan tidak mempunyai kemampuan membayar hutang jangka pendek yang cukup , disebut illikuid (Harnanto, 2012 : 173). Dengan demikian, dapat dikatakan bahwa likuiditas adalah menunjukkan kemampuan suatu perusahaan untuk memenuhi kewajiban keuangannya yang harus segera dipenuhi atau pada saat tertagih.

Kemampuan untuk membayar utang jangka pendek dari suatu perusahaan terletak pada atau diukur dari kemampuannya untuk mendapatkan kas (alat pembayaran) atau kemampuannya untuk mengkonversikan aktiva non kas menjadi kas. Pada umumnya aspek likuiditas tidak dipandang hanya pada suatu saat, tetapi dikaitkan dengan satu periode tahun buku atau kadang-kadang diidentifikasikan dengan siklus operasi normal perusahaan. Siklus operasi normal perusahaan adalah jangka waktu yang tercakup sejak dimulainya aktivitas pembelian, produksi, penjualan hingga aktivitas pengumpulan piutang.

Arti pentingnya aspek likuiditas bagi setiap perusahaan, akan sangat dirasakan pada berbagai akibat yang merugikan atau tidak dapat digunakannya kesempatan untuk memperoleh laba, jika perusahaan berada dalam keadaan tidak likuid (illiquid). Dari berbagai akibat yang dapat terjadi karena keadaan yang tidak likuid tersebut, dapatlah dipahami mengapa pengukuran atau penilaian terhadap aspek likuiditas di dalam dunia usaha dianggap sebagai suatu persoalan yang sangat penting. Begitu pentingnya aspek likuiditas ini, sehingga eksistensi perusahaan akan diragukan, apabila perusahaan tidak lagi berkemampuan cukup untuk membayar kewajibankewajiban jangka pendek pada tanggal jatuh temponya. Apabila hal ini terjadi pada perusahaan, berarti penilaian terhadap aspek-aspek yang lain dalam perusahaan itu tidak bermanfaat lagi bagi pihak-pihak berkepentingan.

Rasio Likuiditas adalah rasio yang digunakan untuk mengetahui kemampuan perusahaan dalam memenuhi kewajiban keuangannya pada saat dilakukan penagihan.

Current Ratio, Current ratio ini menunjukkan kemampuan perusahaan untuk membayar hutang yang akan segera jatuh tempo dengan aktiva lancar.

$$
\begin{aligned}
& \text { current ratio } \\
& =\frac{\text { aktiva lancar }}{\text { hutang lancar }} \times 100 \%
\end{aligned}
$$

\subsection{Solvabilitas}

Solvabilitas adalah rasio untuk menilai kemampuan perusahaan untuk membayar seluruh kewajibannya, baik jangka pendek maupun jangka panjang apabila perusahaan dibubarkan. Rasio ini dapat melihat seberapa jauh perusahaan dibiayai oleh utang atau oleh pihak lain dengan kemampuan perusahaan yang digambarkan oleh modal. Jadi, penggunaan jumlah utang perusahaan tergantung pada keberhasilan pendapatan dan ketersedian aktiva yang bisa digunakan sebagai jaminan utang. Semakin tinggi solvabiltas, perusahaan harus semaksimal mungkin meningkatkan labanya agar mampu membiayai dan membayar utang. Apabila tidak mampu menghasilkan laba, dengan demikian, perusahaan tersebut akan bangkrut.

Menurut Kasmir (2012:113), rasio solvabilitas merupakan rasio yang digunakan untuk mengukur sejauh mana aktiva perusahaan dibiayai dengan utang. 
Dalam praktiknya, apabila dari hasil perhitungan, perusahaan ternyata memiliki rasio solvabilitas yang tinggi, hal ini akan berdampak timbulnya risiko kerugian lebih besar, tetapi juga ada kesempatan mendapat laba juga besar. Sebaliknya apabila perusahaan memiliki rasio solvabilitas lebih rendah tentu mempunyai risiko kerugian lebih kecil pula, terutama pada saat perekonomian menurun. Dampak ini juga mengakibatkan rendahnya tingkat hasil pengembalian (return) pada saat perekonomian tinggi.

Rasio Solvabilitas, rasio yang digunakan untuk mengukur sampai berapa jauh aktiva perusahaan dibiayai oleh hutang. Total Debt to Equity Ratio ini menunjukkan bagian bagian dari setiap rupiah modal sendiri yang dijadikan jaminan keseluruhan hutang.

\section{debt to equity ratio}

$$
=\frac{\text { total debt }}{\text { total equity }} \times 100 \%
$$

\subsection{Hipotesis}

Berdasarkan uraian dan hasil temuan penelitian terdahulu, hipotesis yang diajukan dalam penelitian ini dirumuskan sebagai berikut:

1. Current Rasio berpengaruh positif dan signifikan terhadap return saham perusahaan kosmetik yang terdaftar di Bursa Efek Indonesia?

2. Debt to Equty Ratio berpengaruh negatif dan signifikan terhadap return saham perusahaan kosmetik yang terdaftar di Bursa Efek Indonesia?

3. Apakah Return On Asset positif dan signifikan berpengaruh terhadap return saham perusahaan kosmetik yang terdaftar di Bursa Efek Indonesia?

\section{METODE PENELITIAN}

\subsection{Metode Analisis Data}

Analisis data penelitian ini menggunakan metode analisis regresi panel data. regresi panel data adalah penelitian yang menggabungkan antara cross section seperti rumah tangga, negara, perusahaan, dan sebagainya dengan periode waktu.

Sementara itu, (Suliyanto, 2011) mengungkapkan yang dimaksud dengan analisis regresi panel data adalah regresi yang menggunakan panel data atau pool data yang merupakan kombinasi dari data time series dan data cross section. Penulis menggunakan software Eviews 10 sebagai bantuan dalam melakukan analisis data.

Berikut ini adalah metode yang digunakan dalam menganalisis data pada penelitian ini:

\section{a. Pengujian Model Regresi}

Ghazali, 2013, dalam penelitian ini penulis menggunakan metode analisis regresi berganda dengan data panel. Data panel merupakan penelitian yang menggabungkan antara cross section (data silang) dengan time series (runtun waktu). Dalam menganalisis data menggunakan metode analisis regresi panel data, diawali dengan melakukan polling data dalam bentuk workfile. Berikut ini langkah-langkah dalam estimasi model regresi.

Model persamaan dasar dasar data panel adalah:

Yit $=\beta 0+\beta 1 X 1+\beta 2 X 2+\beta 3 X 3+e i$ Dimana:

$\beta 0 \mathrm{i}=$ konstanta model regresi pada unit observasi ke i

$\beta 1-\beta 4=$ koefisien regresi

e $=$ standar error

Yit $\quad=$ Return Saham

X1it = Likuiditas (CR) 
Invoice: Jurnal Ilmu Akuntansi

p-ISSN: 2714-6359 e-ISSN: 2714-6340

Vol.2 Nomor 2 Agustus 2020

X2it = Solvabilitas (DER)

X3it = Profitabilitas (ROA)

\section{b. Uji Signifikansi}

Dalam pengujian hipotesis ini, pengolahan data menggunakan software Eviews 10. Dan juga menggunakan uji statistik meliputi Uji t (Uji regresi secara parsial) Uji F ( Uji regresi Secara Simultan)

\section{c. Definisi Operasional Variabel}

Definisi Operasional Variabel yang digunakan dalam penelitian ini adalah:

Tabel 2. Definisi Operasional

\begin{tabular}{|c|c|c|c|c|}
\hline No. & Variabel & Konsep variabel & Indikator & Skala \\
\hline 1 & $\begin{array}{l}\text { Return } \\
\text { On Aset } \\
\text { (ROA) }\end{array}$ & $\begin{array}{l}\text { Pengukuran kinerja keuangan } \\
\text { pada penelitian ini menggunakan } \\
\text { pengukuran kinerja konvensional } \\
\text { yang diukur dengan berdasarkan } \\
\text { pada nilai rasio keuangan ROA. } \\
\text { ROA merupakan rasio yang } \\
\text { mengukur } \\
\text { manajemen kemampuan } \\
\text { memperoleh keuntungan secara } \\
\text { keseluruhan selama periode } \\
\text { tertentu. }\end{array}$ & $\mathrm{ROA}=\frac{\text { Laba Bersih }}{\text { Total Asset }} X 100 \%$ & Rasio \\
\hline 2 & $\begin{array}{l}\text { Current } \\
\text { ratio } \\
(C R)\end{array}$ & $\begin{array}{lr}\text { Rasio ini } & \text { dimanfaatkan dalam } \\
\text { mengukur } & \text { kemampuan } \\
\text { perusahaan untuk membayar } \\
\text { kewajiban jangka pendek }\end{array}$ & $\begin{array}{l}\text { current ratio }= \\
\text { aktiva lancar } \\
\text { hutang lancar }\end{array}$ & Rasio \\
\hline 3 & $\begin{array}{l}\text { Debt to } \\
\text { equity } \\
\text { ratio } \\
\text { (DER) }\end{array}$ & $\begin{array}{l}\text { rasio yang digunakan untuk } \\
\text { mengukur sampai berapa jauh } \\
\text { aktiva perusahaan dibiayai oleh } \\
\text { hutang. Debt to Equity Ratio ini } \\
\text { menunjukkan bagian bagian dari } \\
\text { setiap rupiah modal sendiri yang } \\
\text { dijadikan jaminan keseluruhan } \\
\text { hutang. }\end{array}$ & $\begin{array}{l}\text { Debt to equity ratio }= \\
\frac{\text { total debt }}{\text { total equity }} \times 100 \%\end{array}$ & Rasio \\
\hline 4 & $\begin{array}{l}\text { Return } \\
\text { Saham }\end{array}$ & $\begin{array}{l}\text { Return merupakan hasil yang } \\
\text { diperoleh dari sebuah investasi. } \\
\text { Return dapat berupa return } \\
\text { realisasi (realized return) yaitu } \\
\text { return yang telah terjadi atau } \\
\text { return ekspektasi (expected } \\
\text { return) yaitu return yang } \\
\text { diharapkan akan terjadi di masa } \\
\text { yang akan datang }\end{array}$ & $\begin{array}{l}\text { Return Saham }=\frac{P t-(P t-1)}{P t-1} \\
P t: \text { Harga Saham Waktu } \\
\text { Tertentu } \\
P t-1: \text { Harga Saham Periode } \\
\text { Sebelumnya }\end{array}$ & Rasio \\
\hline
\end{tabular}


Invoice: Jurnal Ilmu Akuntansi

p-ISSN: 2714-6359 e-ISSN: 2714-6340

Vol.2 Nomor 2 Agustus 2020

\section{HASIL DAN PEMBAHASAN}

\subsection{Hasil Penelitian}

Tabel 3.

Analisis Deskriptif Statistik

\begin{tabular}{|l|c|c|c|c|}
\hline & $\begin{array}{c}\text { RETURN_SAHA } \\
\text { M }\end{array}$ & CR & DER & ROA \\
\hline Mean & -0.036320 & 262.0892 & 0.885200 & 10.35880 \\
\hline Median & -0.058000 & 211.2200 & 0.610000 & 5.030000 \\
\hline Maximum & 0.750000 & 575.9100 & 2.650000 & 46.66000 \\
\hline Minimum & -0.406000 & 60.56000 & 0.210000 & -17.77000 \\
\hline Std. Dev. & 0.250411 & 161.4373 & 0.755823 & 16.74494 \\
\hline
\end{tabular}

Sumber: Output Eviews 10,2020

\section{a. Return Saham}

Berdasarkan Tabel 4, hasil Eviews untuk uji statistik deskriptif variabel independen Return Saham menunjukkan sampel (N) sebanyak 25, yang diperoleh dari data per tahun periode tahun 20142018. Hasil dalam penelitian ini merupakan hasil dari Return Saham selama tahun publikasi dalam rangka memenuhi uji normalitas data.

Pada tabel Return Saham dari 25 sampel tersebut, dapat dilihat bahwa nilai Return Saham minimum yang diwakili oleh MRAT sebesar -0.406 pada tahun 2015, sedangkan nilai Return Saham maksimum yang diwakili oleh TCID sebesar 0.75 pada tahun 2017 dengan rata-rata sebesar-0.036320.

Standar deviasi sebesar 0.250411 yang berarti kecenderungan data Return Saham ditiap tahunnya selama tahun penelitian mempunyai tingkat penyimpangan sebesar 0.250411 .

\section{b. Current Rasio (CR)}

Berdasarkan Tabel 4, hasil Eviews untuk uji statistik deskriptif variabel independen Current Rasio menunjukkan sampel (N) sebanyak 25, yang diperoleh dari data per tahun periode tahun 20142018. Hasil dalam penelitian ini merupakan hasil dari Current Rasio selama tahun publikasi dalam rangka memenuhi uji normalitas data.

Pada tabel Current Rasio dari 25 sampel tersebut, dapat dilihat bahwa nilai Current Rasio minimum yang diwakili oleh TCID sebesar 60.56 pada tahun 2018, sedangkan nilai Current Rasio maksimum yang diwakili oleh ULVR sebesar 575.91 pada tahun 2016 dengan rata-rata sebesar 262.0892.

Standar deviasi sebesar 161.4373 yang berarti kecenderungan data Current Rasio ditiap tahunnya selama tahun penelitian mempunyai tingkat penyimpangan sebesar 161.4373 .

\section{c. Debt to Equity Ratio (DER)}

Berdasarkan Tabel 4, hasil Eviews untuk uji statistik deskriptif variabel independen Debt to Equity Ratio menunjukkan sampel (N) sebanyak 25, yang diperoleh dari data per tahun periode tahun 2014-2018. Hasil dalam penelitian ini merupakan hasil dari Debt to Equity Ratio selama tahun publikasi dalam rangka memenuhi uji normalitas data.

Pada tabel Debt to Equity Ratio dari 25 sampel tersebut, dapat dilihat bahwa nilai Debt to Equity Ratio minimum yang diwakili oleh MRAT sebesar $0.21 \%$ pada tahun 2014, sedangkan nilai Debt to Equity Ratio maksimum yang diwakili 
Invoice: Jurnal Ilmu Akuntansi

p-ISSN: 2714-6359 e-ISSN: 2714-6340

Vol.2 Nomor 2 Agustus 2020

oleh TCID sebesar $2.65 \%$ pada tahun 2015 dengan rata-rata sebesar 0.885200 .

Standar deviasi sebesar 0.755823 yang berarti kecenderungan data Debt to Equity Ratio ditiap tahunnya selama tahun penelitian mempunyai tingkat penyimpangan sebesar 0.755823 .

\section{d. Retrun On Assets (ROA)}

Berdasarkan Tabel 5, hasil Eviews untuk uji statistik deskriptif variabel independen Return On Asset menunjukkan sampel (N) sebanyak 25, yang diperoleh dari data per tahun periode tahun 2014-2018. Hasil dalam penelitian ini merupakan hasil dari Return On Asset selama tahun publikasi dalam rangka memenuhi uji normalitas data. Pada tabel Descriptive Statistic dari 25 sampel tersebut, dapat dilihat bahwa nilai Return On Asset minimum yang diwakili oleh MBTO sebesar -17.77\% pada tahun 2015, sedangkan nilai Return On Asset maksimum yang diwakili oleh ULVR sebesar $46.66 \%$ pada tahun 2018 dengan rata-rata sebesar 10.35880 .

Standar deviasi sebesar 16.74494 yang berarti kecenderungan data Return On Asset ditiap tahunnya selama tahun penelitian mempunyai tingkat penyimpangan sebesar 16.74494 .

\section{e. Penentuan Model Regresi $\mathrm{Y}=0.110602-0.001370 \mathrm{X} 1+$ $0.238393 \times 2+0.000096 \mathrm{X} 3+\mathrm{ei}$}

Dari persamaan tersebut dapat dijelaskan bahwa:

1) Konstanta sebesar 0.110602 mengindikasikan bahwa secara umum apabila CR, DER, dan ROA bernilai konstan (tidak berubah) maka return saham sebesar 0.110602 poin.

2) Koefisien CR (X1) sebesar -0.001370 mengindikasikan bahwa CR (X1) berpengaruh negatif terhadap Return
Saham (Y). Hal ini berarti terjadinya peningkatan CR (X1) sebesar 1 poin maka akan menurunkan Return Saham (Y) sebesar - 0.001370 poin.

3) Koefisien DER (X2) sebesar 0.238393 mengindikasikan bahwa DER (X2) berpengaruh positif terhadap Return Saham (Y). Hal ini berarti terjadinya peningkatan DER (X2) sebesar 1 poin maka akan meningkatkan Return Saham (Y) sebesar 0.238393 poin.

4) Koefisien ROA (X3) sebesar 0.000096 mengindikasikan bahwa ROA (X3) berpengaruh positif terhadap Return Saham (Y). Hal ini berarti terjadinya peningkatan ROA (X3) sebesar 1 poin maka akan meningkatkan Return Saham (Y) sebesar 0.000096 poin.

\section{f. Uji t (Uji Parsial)}

Uji statistik $t$ dalam penelitian ini dapat dilihat pada nilai probabilitas $t$ statistic. Uji statistik t dilakukan untuk menunjukkan seberapa jauh pengaruh CR, DER, dan ROA secara individual terhadap Return Saham.

Jika nilai probabilitas $t$-statistic lebih besar dari tingkat signifikansi $\alpha=$ 0.05 atau 5\% maka secara parsial variabel independen tidak berpengaruh signifikan terhadap variabel dependen. Sebaliknya jika nilai probabilitas $t$ statistic lebih kecil dari tingkat signifikansi $\alpha=0.05$ atau 5\% maka secara parsial variabel independen berpengaruh signifikan terhadap variabel dependen.

Dari tabel 10, diketahui tingkat signifikansi variabel bebas terhadap variabel terikat. Berikut akan dijelaskan secara parsial pengaruh masing-masing variabel dalam penelitian: 
Invoice: Jurnal Ilmu Akuntansi

p-ISSN: 2714-6359 e-ISSN: 2714-6340

Vol.2 Nomor 2 Agustus 2020

\section{g. Pengaruh Current Ratio (X1)} terhadap Return Saham (Y)

Hasil pengujian dengan analisis regresi data panel menunjukan nilai coefficient Current Ratio (X1) sebesar 2.317879 yang menunjukan bahwa arah koefisien negatif, sedangkan niali probabilitas Current Ratio (X1) sebesar $0.0332<0.05$ menyebabkan H0 diterima dan Ha ditolak. Sehingga dapat disimpulkan bahwa Current Rasio (X1) berpengaruh negatif dan signifikan terhadap Return Saham (Y).

\section{h. Pengaruh Debt to Equity Ratio (X2) terhadap Return Saham (Y)}

Hasil pengujian dengan analisis regresi data panel menunjukan nilai coefficient Debt to Equity Ratio (X2) sebesar 1.036494 yang menunjukan bahwa arah koefisien positif, sedangkan niali probabilitas Debt to Equity Ratio sebesar $0.3145>0.05$ menyebabkan H0 diterima dan Ha ditolak. Sehingga dapat disimpulkan bahwa Debt to Equity Ratio (X2) berpengaruh positif dan tidak signifikan terhadap Return Saham (Y).

\section{i. Pengaruh Return on Asset (X3) terhadap Return Saham (Y)}

Hasil pengujian dengan analisis regresi data panel menunjukan nilai coefficient Return on Asset sebesar 0.010598 yang menunjukan bahwa arah koefisien positif, sedangkan niali probabilitas Return on Asset (X3) sebesar $0.9917>0.05$ menyebabkan H0 diterima dan Ha ditolak. Sehingga dapat disimpulkan bahwa Return on Aset (X3) berpengaruh positif dan tidak signifikan terhadap Return Saham (Y). 0.563041

\section{j. Uji F (Uji Simultan)}

Uji $F$ digunakan untuk mengetahui besarnya pengaruh variabel CR, DER, dan ROA secara simultan terhadap Return
Saham. Pengujian secara simultan atau uji $F$ digunakan untuk mengetahui pengaruh variabel independen secara bersama-sama terhadap variabel dependen. Apabila probabilitas $<0.05$ maka HO ditolak dan $\mathrm{Ha}$ diterima sehingga dapat disimpulkan bahwa variabel independen berpengaruh signifikan secara simultan terhadap variabel dependen. Sedangkan apabila nilai probabilitasnya $>0.05$ maka $\mathrm{HO}$ diterima dan Ha ditolak sehingga dapat disimpulkan bahwa variabel independen secara simultan tidak berpengaruh signifikan terhadap variabel dependen.

Berdasarkan hasil uji $\mathrm{F}$ dapat dilihat bahwa nilai probabilitas $F$ - statistic sebesar $0.021824<0,05$, sehingga $\mathrm{H}_{0}$ ditolak dan $\mathrm{H}_{\mathrm{a}}$ diterima. Dengan demikian dapat disimpulkan bahwa secara simultan terdapat pengaruh yang signifikan antara variabel independen (CR, DER, dan ROA) terhadap Return Saham.

\section{k. Uji Determinasi}

Koefisien Determinasi digunakan untuk mengetahui seberapa besar kemampuan model dalam penelitian menerangkan variabel dependen besarnya nilai $R$-squared adalah 0.5735 . Hal ini menujukkan Return Saham dapat dijelaskan oleh variabel (CR, DER, dan ROA) sebesar 57,35\%. Sedangkan sisanya 52,65 dijelaskan oleh faktor lain diluar variabel penelitian.

\subsection{Pembahasan}

a. Pengaruh Current Ratio (CR) terhadap Return Saham

Berdasarkan hasil pengujian didapati hasil variabel Current Ratio memiliki pengaruh negatif dan signifikan terhadap Return Saham. Sementara dari hasil uji parsial (uji t), didapati bahwa 
Current Ratio memiliki pengaruh yang signifikan terhadap Return Saham di Perusahaan Kosmetik yang terdaftar di Bursa Efek Indonesia, hasil ini berarti Current Ratio berpengaruh terhadap Return Saham. Dengan demikian dapat dikatakan Current Ratio merupakan faktor penentu meningkat dan turunnyanya Return Saham pada Perusahaan Kosmetik yang terdaftar di Bursa Efek Indonesia.

Dalam penelitian ini bahwa Current Ratio (CR) memiliki hasil negatif. Current Ratio (CR) berpengaruh negatif terhadap return saham pada perusahaan food and baverages artinya perusahaan yang memiliki nilai Current Ratio (CR) yang tinggi belum pasti akan menghasilkan imbal balik return saham yang tinggi dan pembayaran utang akan terpenuhi apabila perusahaan sudah jatuh tempo. Dapat disebabkan oleh nilai jumlah persediaan yang tinggi dibandingkan taksiran penjualan yang akan datang, sehingga akan menunjukkan kelebihan persediaan serta memperlihatkan bahwa perusahaan tidak bisa memaksimalkan persediaan yang ada.

"Apabila rasio lancar (Current Ratio) rendah, dapat dikatakan bahwa perusahaan kurang modal untuk membayar utang. Namun, Apabila hasil pengukuran rasio tinggi, belum tentu kondisi perusahaan sedang baik. Hal ini dapat saja terjadi karena aktiva tidak digunakan sebaik mungkin" (Kasmir, 2015:135). Berdasarkan pendapat para ahli diatas dapat memperkuat atau menjadi acuan bahwa Ketidakjelasan kondisi Current Ratio ini menjadi dasar bagi investor tidak menggunakan informasi Current Ratio, sehingga tidak dapat mempengaruhi investor dalam pengambilan keputusan investasinya.
Hasil penelitian ini mendukung hasil dari penelitian Yulia Wingsih (2016) yang hasilnya menunjukkan bahwa Current Ratio berpengaruh negatif terhadap return saham.

\section{b. Pengaruh Debt to Equity Ratio (DER) terhadap Return Saham}

Berdasarkan hasil pengujian didapati hasil variabel Debt to Equity Ratio memiliki pengaruh positif dan tidak signifikan terhadap Return Saham. Sementara dari hasil uji parsial (uji t), didapati bahwa Debt to Equity Ratio memiliki pengaruh yang tidak signifikan terhadap Return Saham di Perusahaan Kosmetik yang terdaftar di Bursa Efek Indonesia, hasil ini berarti Debt to Equity Ratio tidak berpengaruh terhadap Return Saham. Dengan demikian dapat dikatakan Debt to Equity Ratio bukan merupakan faktor penentu meningkat dan turunnyanya Return Saham pada Perusahaan Kosmetik yang terdaftar di Bursa Efek Indonesia.

DER berpengaruh tidak signifikan disebabkan oleh perbandingan modal sendiri dan modal yang dibiayai utang bukan hanya pengaruh kinerja manajemen, tetapi faktor lainnya maka DER tidak menjadi acuan investor dalam berinvestas. Pengaruh yang tidak signifikan dari DER terhadap return saham juga dapat berarti bahwa ada penilaian yang berbeda dari investor terhadap arti pentingnya hutang bagi perusahaan. Beberapa investor dapat berpikir bahwa DER yang besar akan menjadi beban bagi perusahaan karena adanya kewajiban dari perusahaan untuk membayar hutang dan adanya resiko kebangkrutan yang akan ditanggung oleh investor. Di sisi lain beberapa investor juga berpendapat bahwa hutang sangat dibutuhkan oleh perusahaan untuk operasional perusahaan. Hutang 
diperlukan oleh perusahaan untuk menambah modal perusahaan karena dengan memiliki hutang yang besar dapat digunakan untuk meningkatkan modal perusahaan sehingga perusahaan dapat mengembangkan usahanya dan dengan melakukan pengembangan usaha maka investor lebih tertarik untuk membeli saham perusahaan tersebut.

DER merupakan rasio yang digunakan untuk mengukur tingkat leverage dalam menunjukkan kemampuan perusahaan untuk memenuhi kewajiban jangka panjang. Semakin tinggi DER menunjukkan komposisi hutang semakin besar dibandingkan dengan total modal sendiri, hal ini menunjukkan sumber modal perusahaan tergantung dari pihak luar, sehingga akan mengurangi minat investor untuk menanamkan modalnya diperusahaan yang memiliki DER tinggi. Menurunnya minat investor berdampak pada penurunan harga saham yang berakibat terhadap menurunnya total return perusahaan (Kasmir, 2015).

Hasil penelitian ini mendukung hasil dari penelitian Fajar Indrawan Bur (2012), yang hasilnya menunjukkan bahwa Hasil penelitian Debt to Equity Ratio (DER) tidak berpengaruh terhadap Return Saham.

\section{c. Pengaruh Return on Asset (ROA) terhadap Return Saham}

Berdasarkan hasil pengujian didapati hasil variabel Return on Asset memiliki pengaruh positif dan tidak signifikan terhadap Return Saham. Sementara dari hasil uji parsial (uji t), didapati bahwa Return on Asset memiliki pengaruh yang tidak signifikan terhadap Return Saham di Perusahaan Kosmetik yang terdaftar di Bursa Efek Indonesia, hasil ini berarti Return on Asset tidak berpengaruh terhadap Return Saham.
Dengan demikian dapat dikatakan Return on Asset bukan merupakan faktor penentu meningkat dan turunnyanya Return Saham pada Perusahaan Kosmetik yang terdaftar di Bursa Efek Indonesia.

Tidak berpengaruh variabel return on asset pada return saham dikarenakan minimnya return on asset yang menyebabkan tingginya aset perusahaan yang tidak digunakan, investasi pada persediaan yang sangat tinggi, lebihnya dana, dan aktiva tetap beroperasi di bawah normal.. Hasil penelitian ini menunjukkan bahwa ROA tidak berpengaruh terhadap return saham karena dapat diindikasikan bahwa tinggi atau rendahnya ROA tidak dijadikan tolak ukur investor dalam melakukan investasi di suatu perusahaan.

Hal ini sejalan dengan penelitian Muhammad Reza Alviansyah, et al (2018), berjudul Pengaruh Profitabilitas, Leverage, dan kuran Perusahaan Terhadap Return Saham. Hasil penelitian ROA berpengaruh positif tidak signifikan terhadap return saham.

\section{PENUTUP}

\subsection{Simpulan}

1. Current Ratio memiliki pengaruh negatif dan signifikan terhadap Return Saham pada Perusahaan Kosmetik yang terdaftar di Bursa Efek Indonesia.

2. Debt to Equity Ratio memiliki pengaruh positif dan tidak signifikan terhadap Return Saham pada Perusahaan Kosmetik yang terdaftar di Bursa Efek Indonesia.

3. Return on Asset (ROA) memiliki pengaruh positif dan tidak signifikan terhadap Return Saham pada Perusahaan Kosmetik yang terdaftar di Bursa Efek Indonesia. 


\subsection{Saran}

1. Dalam hal ini pengelolaan hutang yang baik, adalah dengan cara pengurangan hutang perusahaan dengan mengurangkan aktiva lancar berupa kas sehingga hutang berkurang, dan presentase dari DER akan lebih kecil, seiring hal tersebut maka tingkat return saham akan meningkat.

2. Selain itu, dalam pengelolaan asset terutama asset lancar dalam hal ini untuk meningkatkan tingkat current ratio harus dilakukan secara efektif dan efisien, pengelolaan asset secara efisien ini dilakukan agar bisa meningkatkan tingkat likuiditas perusahaan khususnya perusahaan kosmetik ini. Maka, ketepatan dalam penggunaan asset ini sangatlah penting. Dalam hal ini yang dapat dilakukan perusahaan dalam pemanfaatan asset lancarnya adalah penggunaan asset lancar dalam bentuk kas untuk mengurangi hutang lancarnya, sehingga tingkat current rationya dapat meningkat dan return saham yang didapatkan akan meningkat.

3. Selain itu dalam hal profitabilitas pada perusahaan kosmetik ini perlu meningkatkan lagi ROA pada perusahaan tersebut. Untuk meningkatkan nilai ROA atau Return on Assets kita dapat meningkatkan margin (tentunya harga diterima pasar) atau mengurangi biaya. Selain itu perusahaan dapat meningkatkan frekuensi penjualan atau meningkatkan perputaran persediaan (inventory turnover). Sehingga profitabilitas atau dalam hal ini ROA akan semakin meningkat dan return saham akan meningkat.
4. Untuk penelitian selanjutnya diharapkan agar mengembangkan penelitian ini dengan menambahkan variabel-variabel lain yang dapat mempengaruhi profitabilitas perusahaan.

\section{REFERENSI}

Adisasmita R, Sakti A. 2010. Teori Pertumbuhan Kota (Perkotaan). Makassar: Universitas Hasanuddin

Agus Sartono. 2010. Menejemen Keuangan Teori dan Aplikasi. Edisi 4. BPFE Yogyakarta

Ahmad Sandy dan Nur Fadjrih Asyik. 2013. Pengaruh Profitabilitas dan Likuiditas terhadap Kebijakan Dividen Kas pada Perusahaan Otomotif. Jurnal Ilmu dan Riset Akuntansi. Vo.1. No.1.

Ang, Robert. 1997. Buku Pintar Pasar Modal Indonesia (The Intelligent Guide to Indonesian Capital Market). Jakarta: Mediasoft Indonesia.

Bambang Riyanto. 2010. Dasar-Dasar Pembelanjaan Perusahaan, ed. 4, BPFE-YOGYAKARTA.

Dedi Rosadi. (2012). Ekonometrika dan Analisis Runtun Waktu Terapan dengan Eviews. Yogyakarta : Andi Offset

Fahmi, Irham. 2011. Analisis Laporan Akuntansi. Bandung: Alfabeta 2012. Analisis Kinerja Keuangan , Bandung: Alfabeta

Ghozali, Imam, \& Dwi Ratmono. 2013. Analisis Multivariat dan Ekonometrika. Semarang: Universitas Diponegoro 
Ghozali, Imam. 2011. Aplikasi Analisis Multivariat dengan Program IBM SPSS 19 edisi 5. Semarang: Badan Penerbit Universitas DiponegoroGitman, L.J.; Zutter, C.J. 2012. Principles of Managerial Finance. 13e. Boston: Pearson.

Gujarati, Damodar N. 2010. Dasar-dasar Ekonometrika. Jakarta: Salemba Empat

Hanafi, M.M. \& Abdul, H. 2003. Analisis Laporan Keuangan. Yogyakarta: UPP AMP YKPN.

Harjono Sunardi. 2010. Pengaruh Penilaian Kinerja dengan ROI dan EVA terhadap Return Saham pada Perusahaan yang Tergabung dalam Indeks LQ 45 di Bursa Efek Indonesia. Jurnal Akuntansi, Vol.2 No.1 Hal: 70-92

Hartono, Jogiyanto. 2017. Teori Portofollio dan Analisis Investasi, Edisi kesebelas. Yogyakarta: BPEE

Husnan, Suad. 1996. Teori Portofolio Dan Analisis Sekuritas. UPP AMP YKPN - Yogyakarta 2001. Dasar-Dasar Teori Portofolio Dan Analisis Sekuritas. AMP YPKN. Yogyakarta.

\section{Manajemen}

Keuangan : Teori dan Penerapan Buku 1. Edisi 4. BPFE. Yogyakarta

Ifa, N. (2017). Analisis Current Ratio, Return on Equity, Debt to Equity Ratio dan Pertumbuhan pendapatan berpengaruh terhadap return saham pada perusahaan pertambangan di Bursa Efek Indonesia 2010-2014. Jurnal Kreatif. Vol.5 No.1
Indriantoro, Nur and Bambang Supomo. 2014. Metodologi Penelitian Bisnis Untuk Akuntansi \& Manajemen. Edisi 1. Cetakan ke-12. Yogyakarta: BPFE.

2015. Analisis Laporan Keuangan. Cetakan Kedelapan. PT Rajagrafindo Persada. Jakarta.

. 2016. Analisis Laporan Keuangan. Jakarta: Raja Grafindo Persada.

Jogiyanto, 2017, teori Porotofolio Edisi kesebelas BPFE, Yogyakarta

Sugiyono, 2013. Metode Penelitian Kuantitatif, Kualitatif, R\&D. Bandung: CV. Alfabeta. 2016. Metode Penelitian Kuantitatif, Kualitatif dan R\&D. Bandung: Alfabeta.

Yulia, W. 2013. Analisis Pengaruh Likuiditas, Profitabilitas Dan Solvabilitas Terhadap Return Saham Pada Perusahaan Pertambangan Yang Terdaftar Di Bursa Efek Indonesia Pada Tahun 2008 Sampai 2012. 